\title{
Classroom Talk as a Classroom Management Practice at Junior High School
}

\author{
Endah Nur Tjendani \\ English Education, Faculty of Teacher Training and Education \\ Universitas Islam Jember \\ tjendani.endah@gmail.com
}

\begin{abstract}
Teacher is the most important person who has to manage the class activities. As a manager, teacher has to control the real action of the lesson planning into the classroom, so the investigation was stressed on the teaching preparation as a written plan and the sequences of classroom talk as the verbal practices applied by classroom English teacher at Junior High School. Interview and in-depth observation in three classrooms activities were selected as a data collecting method, and IRE/F was for analyzing the verbal activities. The data gained were in the forms of text and talk. The findings of the research are the most of initiation talk came from the teacher who used display and choice questions, the students responded by reading books individually or by giving short responses chorally and evaluation was based on doing workbook exercises. Furthemore, the lesson plan could not be implemented well in the classroom, because the sequences of classroom talk dominated by teacher's information and direction which followed the teaching materials design, and it limited students' opportunities to explore, to ask questions, to explain, or to give comment, but the students' responses are doing exercises most of the time, and then answer it one by one. The sequences of classroom talk also limited whose ideas were heard and whose mistakes got feedback.
\end{abstract}

Keywords-classroom talk, classroom management practice, Junior High Shool

\section{INTRODUCTION}

Classroom is the best possible learning environment for student at school. The class arrangement is started from the teacher who makes decision on stating objectives and adapting the lesson from some sources books in different ways to suit it better into the classroom activities. The process of planning is an essential part of transforming ideas of the teacher as a manager who creates a lesson planning and manages the classroom activities during the lesson as an acting and controlling phase. The lesson planning is a written preparation which consists of what a lesson plan provides (students' needs, objectives, time), contents (context, activities and class organization, media, language, possible problems), and evaluation system (test or non-test). It also organizes the portion of all teaching learning components, like the teacher's role, the students' role, the material's role, and the evaluation role in the classroom activities, and the teacher is the manager who shares and makes decisions on every role and on every teaching learning step in the classroom activities. [1] [2] The main purposes of the classroom management are to control the class in the way of motivating students, managing constraints, and managing the role of learning aspects.
To manage the class activities during the lesson is the main task of the teacher. It means that the teacher has been applying the lesson planning for students' learning, while good classroom arrangement is not a guarantee of good learning behavior, poor planning in this area can create conditions that lead to problems. [3] The role of teacher in this case is to construct learning situation, like setting behavior expectation, managing academic task, managing inappropriate behavior, promoting appropriate use of consequences, sequencing the classroom talk, setting up the different types of learning and teaching strategies; individual, peers or group, etc. Although there are many recommendations ways to organize learning, lessons still dominated by teacher-fronted interactions and inundated with teacher talk. [4] [5] [6] [7] The language used for making a good communication with the students is important as the main purposes of schooling to achieve the lesson goal. It is very common that teachers use talk or language for controlling the class; engaging, exploring, explaining, and correcting. The classroom talk is considered as asymmetrical interaction with the pattern of IRF/E - initiation, response and feedback/evaluation. And there are so many studies related to this kind of interaction.

Previous studies related to classroom communication shown that [8] the teacher tented to dominate the classroom discourse with 341 utterances, students' talk around 104, and coral 31 responses. Research on teacher questions [9] reported that teacher used $66.7 \%$ of display questions and $33.3 \%$ referential questions. The following research [10] shown that students responded in a few words or in simple questions. The teacher took $93 \%$ of teaching time for teacher-students interaction, and $7 \%$ of teaching time for student-student interaction. The students had limited opportunities to take part in class interaction. The pattern of classroom interaction had been dominated by the teachers. All the researches were focused on the interaction models, like; scaffolding, direct repair, content feedback, referential questions, extended teacher turn, extended students turn, turn completion, seeking clarification, and confirmation check. The classroom research have been explored to the effective classroom interaction strategies to drive student language development. To make the classroom situation and condition effective, the teacher has to sequences the activities by sharing the time and roles to the whole instructional components.

The effectiveness of a teacher in the classroom can be influenced by the preparation which has gone into the lesson. On the other hand, classroom talk is inisiated by the teacher in which how the teacher choose the language for making 
context of a lesson, how to share the time for discussion and doing task, how to engage teaching to encourages ongoing talk between students and teacher, and how to check understanding of the students exploratory talk which includes offering opinions, giving reasons to support others opinions, seeking views each other, and checking agreement. The classroom talk is as a classroom management practice which controls the teaching planning with what is going on during a lesson in class.

\section{RESEARCH METHODOLOGY}

This research was related to classroom language setting discourse, so discourse analytical approach to text and talk was applied in term of its relationship between micro- and macro analytical approach. [11] The functional analysis of classroom talk allowed the principle of how language works within the professional terminology written in the teachers' planning and the classroom interaction talk. The elicitation sequences composed of teacher initiation, student responses, and teacher evaluation/feedback (IRE/F) as a basic unit of instructional interaction. For this reason, the data had been collected by using interview and in-depth observation in three classrooms activities and had been recorded. The printed data were the lesson plans which written by the class English teachers, and the verbal practices data were from classroom communication.

The corpus data was designed for classifying data; 1) teacher talk (instruction, explanations, questions, appreciation, response), 2) students talk (giving response, opinion, answer, questions), and 3) class activities (doing task, giving correction, giving reward, giving punishment). All the data were analyzed in three ways; the first level of analysis sought to identify the lesson sequences activities of lesson plan as the printed management preparation of the teacher, the second level of analysis aimed to identify the modes of language used based on IRE/F frame work, and last analysis was to classify the learning activities.

\section{RESEARCH RESULTS AND THEIR DISCUSSION}

This research had been done at Public Junior High School in Jember, moreover the interview and the observation were conducted at three different English teacher in different classes, and the students of those classes. The data were a lesson plan as a text and a classroom talk transcripts as a verbal practices. The text data are from:

a) Lesson Plan 1 (LS1) was for teaching reading and speaking skills: Procedure text - topic: How to Make a Drink,

b) Lesson Plan 2 (LS2) was for teaching reading skills: Passages - topic: The White House for Reading Skills, and

c) Lesson Plan 3 (LS3) was for teaching writing skills: topic: Let's Learn to Construct Texts.

\section{Planning}

The major sequences activities from lesson plans were divided into three parts, they are opening/warming up, main activities, and closing/feedback. This planning is a part of instructional which involve anything from setting up behavior to the detailed written procedure for the lesson. The behavior expectations were consisted of competencies, rules, and procedures which were used for helping teacher to manage classroom interactions and to share every role of instructions from the beginning up to the end of the lesson period. The planned activities shown as follows:

TABLE I. SEQUENCES ACTIVITIES BASED ON LESSON PLAN

\begin{tabular}{|c|c|c|c|}
\hline $\begin{array}{c}\text { Stag } \\
\text { es }\end{array}$ & $\begin{array}{c}\text { LS1 activities for } \\
\text { Teacher } 1\end{array}$ & $\begin{array}{c}\text { LS2 activities for } \\
\text { Teacher } 2\end{array}$ & $\begin{array}{c}\text { LS3 activities for } \\
\text { Teacher } 3\end{array}$ \\
\hline $\begin{array}{l}\text { open } \\
\text { ing/ } \\
\text { war } \\
\text { ming } \\
\text { up }\end{array}$ & $\begin{array}{l}\text {-Asking and } \\
\text { answering related to } \\
\text { pictures (beverages), } \\
\text {-Explain how } \\
\text { important to master } \\
\text { the teaching } \\
\text { materials }\end{array}$ & $\begin{array}{l}\text {-Asking and } \\
\text { answering related to } \\
\text { pictures (building), } \\
\text {-Explain how } \\
\text { important to master } \\
\text { the teaching } \\
\text { materials }\end{array}$ & $\begin{array}{l}\text {-Asking and } \\
\text { answering related to } \\
\text { writing activities, } \\
\text {-Explain how } \\
\text { important to master } \\
\text { the teaching } \\
\text { materials }\end{array}$ \\
\hline \multirow[t]{2}{*}{$\begin{array}{l}\text { main } \\
\text { activ } \\
\text { ities }\end{array}$} & $\begin{array}{l}\text { Exploration } \\
\text {-Involving students } \\
\text { to find the } \\
\text { information related } \\
\text { to teaching } \\
\text { materials, } \\
\text {-Reading aloud, } \\
\text {-Facilitating SS to } \\
\text { work together with } \\
\text { T, friends, media } \\
\text { (class surround), } \\
\text {-Using many } \\
\text { learning approaches, } \\
\text {-Involving SS for } \\
\text { active learning, }\end{array}$ & $\begin{array}{l}\text { Exploration } \\
\text {-Involving students } \\
\text { to find the } \\
\text { information related } \\
\text { to teaching } \\
\text { materials, } \\
\text {-Reading aloud, } \\
\text {-Facilitating SS to } \\
\text { work together with } \\
\text { T, friends, media } \\
\text { (class surround), } \\
\text {-Using many } \\
\text { learning approaches, } \\
\text {-Explaining new } \\
\text { vocabularies, } \\
\text { Involving SS for } \\
\text { active learning, }\end{array}$ & $\begin{array}{l}\text { Exploration } \\
\text {-Involving students } \\
\text { to find the } \\
\text { information related } \\
\text { to teaching } \\
\text { materials, } \\
\text {-Facilitating SS to } \\
\text { work together with } \\
\mathrm{T} \text {, friends, media } \\
\text { (class surround), } \\
\text {-Using many } \\
\text { learning approaches, } \\
\text { Involving SS for } \\
\text { active learning, }\end{array}$ \\
\hline & $\begin{array}{l}\text { Elaboration } \\
\text {-Encouraging habit } \\
\text { by reading, writing } \\
\text { and giving } \\
\text { meaningful tasks, } \\
\text {-Giving chances for } \\
\text { thinking, analyzing, } \\
\text { solving problems, } \\
\text { and doing task } \\
\text { without feeling } \\
\text { afraid, } \\
\text {-Discussing task } \\
\text { with friends, } \\
\text {-Showing the results } \\
\text { of task }\end{array}$ & $\begin{array}{l}\text { Elaboration } \\
\text {-Encouraging habit } \\
\text { by reading, writing } \\
\text { and giving } \\
\text { meaningful tasks } \\
\text {-Giving chances for } \\
\text { thinking, analyzing, } \\
\text { solving problems, } \\
\text { and doing task } \\
\text { without feeling } \\
\text { afraid, } \\
\text {-Discussing task } \\
\text { with friends, } \\
\text {-Showing the results } \\
\text { of task }\end{array}$ & $\begin{array}{l}\text { Elaboration } \\
\text {-Encouraging habit } \\
\text { by reading, writing } \\
\text { and giving } \\
\text { meaningful tasks } \\
\text {-Discussing } \\
\text { grammar } \\
\text { (preposition, noun, } \\
\text { verb), } \\
\text {-Giving chances for } \\
\text { thinking, analyzing, } \\
\text { solving problems, } \\
\text { and doing task } \\
\text { without feeling } \\
\text { afraid, task } \\
\text {-Discussing } \\
\text { with friends, } \\
\text {-Showing the results } \\
\text { of task }\end{array}$ \\
\hline
\end{tabular}


PRESS

\begin{tabular}{|l|l|l|l|}
\hline \multicolumn{1}{|c}{ CONT. SEQUENCES ACTIVITIES BASED ON } \\
LESSON PLAN
\end{tabular}

Initials: $\mathrm{S}=$ Student, $\mathrm{SS}=$ Students, $\mathrm{T}=$ Teacher

Based on the data, the structures of classroom talks were scaffolded same among the three class activities, they are double three stages, it means that first three stages is warming up, main activities, and closing, the second one is the main activities which is divided into three parts, like exploration, elaboration, and confirmation. The whole interaction had been written in affirmative sentence stressing on what would be going on in the classroom rather than in form of talking or dialogue.

According to the teachers, these interaction procedures were applied scientific approach, which is promoted by government. [12] The media used and showing the needs of the lesson were shown at the warming up stage after having greeting. The first main activities are created for finding the contextual learning, collaborating and explaining new materials. Second phase is a critical thinking and discussing for doing task, and last phase of main activities is a strengthening of the lesson, especially for correcting tasks. The last written procedure is to give feedback by summarizing the whole lesson. The class action was as controlling of the printed plan. The classroom talk were opened and initiated by the teacher. Language is used as an interaction medium.

Classroom talk

From the research, the language used by the teacher for making a talk with the students was documented on the classroom talk transcript. The corpus data was divided into five structures of talking; they were warming up, exploration, elaboration, confirmation, and giving feedback. All the data related to how the teacher selected the language used for controlling the classroom talk. Although it is the English classes, a medium of instruction was mostly in Indonesia language.

Warming up

The teacher initiated all the class interaction. The first sentences were greeting, like good morning, and how are you? The class interaction was started by teacher who warmed up the situation by saying 'hallo', motivating, and creating learning context. [13] [14] The context ways of greeting was Assalamu'alaikum $w r w b$. The learning context given was that the teacher asked students to open the English textbook and then it begun to discuss first lesson. Like this short talk:

Teacher: How are you?

Students: I am fine. (Chorally)

Teacher: Now open your book and let's read the first lesson.

The different situation happened for some students who forget to bring the books. First was so clumsy situation at the moment, because the teacher had punished some students who didn't have books to run around the schoolyard. It was hoped that the student would bring his book and do not forget it anymore. Second is that the teacher was continuing the lesson.

Students: I am so sorry, Mom; I did not bring a book.

Teacher 1: the students, who do not bring a book, please get out at moment and run around the schoolyard once,

Teacher 2: ... (silent) let's open the book.

The display question was given at the following activities, like what is the descriptive text? Anybody knows? At last opening talk was ended by opening English books, without any talking about pictures.

\section{Exploration}

It was started from reading text aloud which initiated by the teacher, then students listened to the teacher, and then teacher asked student to read randomly. The teacher talk was a direct influence, which needs students' response directly to do what teacher's instruction. [15] The directions are shown:

Teacher 1: I read the passage, and listen to me!

Teacher 2: Listen to me and find the information and difficult words from the passage.

Teacher 3: Please read the descriptive text and find the pattern of the text.

The students' responses were to listen to the teacher 1,2 and to note the difficult words, which they found. But teacher 3 directly asked students to read and find the pattern of descriptive text for writing skills. The explanations of new materials were given after this phase. Asking inference questions to the difficult words and confusion meaning they found had showed the students' initiations.

Student 1: Excuse me, Mom. What is the meaning of view?

Student 2: What is the massage of paragraph 2?

Student 3: What is different between view and panorama? 
The teachers had responded to the question by giving some information directly, like Hmm .. The meaning of ... is... or which one? this paragraph means..The last sentence of explanations was do you understand? And the students answered chorally Yes, I understand. The responces of Hmm... And which one? Refer to the simple acknowledgment. The teacher also remained to the students who make noises, like please don't talk or please don't make noises! Finally, the teachers tended to talk too much in this phase.

Elaboration

At this elaboration part, he students did all the workbook exercises individually or discuss with the desk mate and corrected the works. They wrote the answers in workbook or notebook. These activities spent most of the lesson time. On the other hand, the teachers were sitting at the teachers' desks, and they controlled the class occasionally by saying do you finish, or please do exercises soon, or please don't make a noise, and by moving around the class. The following step was to correct the written responses whether it was true not. It was intended to check the students' answers moderated by the teacher. And the students were busy to prepare the answers.

Teacher 1: Now, let's answer the questions.

Teacher 2: Have you finished doing exercises?

Teacher 3: Let's try to discuss your writing draft.

Students: Yes Sir (Mom)

Teacher1, 2, 3: Are you ready? Let's start from you. (Note one of student)

The student answered the questions one by one, then continuing to the next students when the answer was right, but the teacher gave correction immediately when the answer was wrong. Otherwise, students concerned with task in hand and work-oriented, so this interaction could not be recorded well. This choral response is due to the teachers' commands that students are expected to do the various exercises and drills after having a good understanding of materials.

The teacher 3 (writing skill) asked two students randomly to write the descriptive writing draft on the blackboard. The drafts were as samplings, which were for discussing, and the students could find out the correct opinions coming from the teacher's explanations for getting their own corrections. It used ideas of the students for clarifying, and interpreting, and then the students rephrased their works. The teacher said Pay attention to your friends' works at the black board. I would explain this draft, and you have to rephrase your draft. This interaction provides direct responds, self-correct, and it makes students busy to think and correct their own work. [16]

Confirmation

The teacher initiated the classroom interaction in this part by saying: ok students any difficulties? Or do you have others ideas? Or is there any questions? The teachers offered the opportunity to students to give opinions or to find out what they think difficult or still need to improve. The response of the student was short answer no Sir (Mom), and then the teachers explained a brief about the main part of the lesson. But, at the writing class, there was one student who asked what things can be described?, the teacher answered directy.
The interactions were closed by checking the answers of the students' works once again before lesson ended.

Closing

After confirmation dialogue, the following part was closing which provided for teachers to brief the lesson point, like ok the point of this lesson is... or the point that you have to learn is ... and to ask students to read the answers which were due to the lesson focus. These talk is a kind of summarizing of lesson. Last was clesed bya saying good bye.

Teacher 1: Okay my students, time is over Let's close this meeting by saying good bye

Teacher 2: that is all the lesson today, see you next meeting and good bye

Teacher 3: Don't forget to do your homework for next meeting. Thank for your attantion, good bye.

Students: Good bye, see you next time.

Other talk

The language used by teacher like your answer is good, or great, or right. Many times, the choice question of do you understand? Uttered by the teachers after rephrasing the answer or explaining a certain part of lesson. Hmm, uhh, and smile were a kind of gesture language which mean to give impact for cognitive development in social space.

Based on the description above, it can be said that the lesson plan data presented in table shows that in the managerial planning, the teacher had classified into three parts of activities, they are; warming up, main activities, and closing. The media, as a picture would help to attract the condition vivid. But the classroom talk modes had shown that there was big different between situations which were written at the lesson plan and situations which were initiated in classroom talk. The teacher's perception about punishment at the beginning of teaching has to be corrected at the future. After opening book, the teacher moved to the main activities what was interaction created is the immediate talk which could be improved too.

The following stage was the sequences of main activities were divided into three parts; exploration, elaboration and confirmation which were to manage student academic work and inappropriate behavior. On the other hand, the classroom talks were shown that display questions were developed to be based on the ready-to-use teaching materials as a textbook, like, what is the description text?, or can you give the examples?. The interaction mode had followed the structures of teaching materials, so the management of students academic at the class talks mostly was explaining texts which were related to how to do exercises. The students had discussed with friends to finish their tasks in this moment. Correction toward inappropriate attitudes and wrong answer are directly talked, for examples, you can move to your friend who brings a book, or the correct answer is the White House. To make the students' academic attractive, it is needed to listen more and to dig more about students' ideas or opinions differently, so that the classroom talk would be dominated and initiated by the students systematically, besides the good result of doing task and ideas had to be promoted for having encouragement to attend the following stage of teaching. 
Last was closing stage which was the strengthening phase of whole lesson. The talk was to give the homework and to summarize the lesson. The way how the teacher giving evaluation and feedback were directly during the main activities, especially after the student answered the question or gave responses. It can be conclude that the implementation of lesson plan as a management planning have not specified to prepare an appropriate activities which could be implemented at the classroom talk as a management controlling. The sequences of class activities had followed the pattern of the textbook system as a ready-to use teaching materials.

\section{CONCLUSION}

The conclusion is that the trend of the classroom teaching learning process is on how teacher prepare the lesson plan and then how to talk the plan into the real classroom as a management practice. The sequences of class activities were initiated and dominated by the teacher talk using display and choice questions. On the other hand, the students' responses were dominated by answering the questions on the book, and evaluation and feedback were talked by the teacher directly after the student was giving responses. Last, the sequences of classroom talk also limit whose ideas are heard and whose gets feedback.

Acknowledgment: I offer my highest appreciations to Mr. Ismaul Husni and the audiences who joined ICEMAL 2016 UPI Bandung in Gazania Room for the kind inputs and comments on this manuscript.

\section{REFERENCES}

[1] Farrel, Thomas S.C. 2002. Lesson Planning. In Methodology in language Teaching; an Anthology of Current Practice, edited by Jack Richards, and Renendya Cambridge University Press

[2] Harmer, Jeremy. 2010. The Practice of English Language Teaching. pearson Longman. British

[3] Kizlik, Bob. (2016). Catalyst: Tools for Effective Teaching. http://www.adprima.com/managing.htm.

[4] Lewis, Marilyn. 2002. Classroom Management. In Methodology in language Teaching; an Anthology of Current Practice, edited by Jack Richards, and Renendya Cambridge University Press

[5] Crhristie, Frances. 2002. Classroom Discouse Analysis: A Functional Perspective. Continuum. New York

[6] Goh and Doyle.2014. How to Do Speaking and Writing Sopport each others? In Language in Education Sosial Implications, edited by Rita Elaine Silver and Soe Marlar Lwin, 105-124. Bloomsbury, London.

[7] Silver, Rita Elaine, Roslinda A R., and Galyna Kogut. 2014. How is Language Used for Learning?. In Language in Education Sosial Implications, edited by Rita Elaine Silver and Soe Marlar Lwin, 17-65. Bloomsbury, London.

[8] Milal, A.D (2011). Indicators of Practice of Power in Language Classroom. Teflin Journal, 22(1), 1-15.

[9] Arifin, T. 2012. Analysing English as a Foreign Language (EFL) Classroom Interaction. Apple3L Journal, 1(I), 1-20

[10] Suryati, Nunung. 2015. Classroom Interaction Strategies Employed by English Teachers at Lower Secondary Schools. TEFLIN Journal, 26(2), 247-264.

[11] Baxter, Judith. 2010. Discourse-Analytic Approaches to Text and Talk. In research Method in Linguistics, edited by Lia Litosseliti, page 117137. Continuum International Publishing Group. New York.

[12] Permendikbud. 2013. No. 65, thn. 2013: Standar proses. Depdikbud. Jakarta

[13] Crenmer, David. 1991. The Teacher's Role in the Oral Lesson - a Reminder. In At the Chalk Face. Practical Techniques in Language Teaching, edited by Alan Matthews, et. all. Nelson. Hongkong.
[14] Richards, Jack and Renendya. 2002. Methodology in language Teaching; an Anthology of Current Practice. Cambridge University Press

[15] Brown. 2005. Testing in Language Programs; a Comprehensive Guide to English Language Assessment. Mc Graw Hill.

[16] Dickinson, Leslie. 1988. Seff-instruction in Language Learnig. Cambridge University Press. Cambridge. 